\author{
ARTIGO \\ do $\underline{\text { https://doi.org/10.22481/praxisedu.v16i41.6324 }}$
}

\title{
UNA VITA PER L'EDUCAZIONE: MEMÓRIAS AUTORREFERENCIAIS DA PROFESSORA MARIA MOCELINI (1878 - 1961)
}

\author{
A LIFE FOR EDUCATION: SELF-REFERENCED MEMORIES OF THE TEACHER \\ MARIA MOCELINI (1878-1961) \\ UNA VIDA POR LA EDUCACIÓN: MEMORIAS AUTO-REFERENCIALES DE LA \\ PROFESORA MARIA MOCELINI (1878 - 1961)
}

Gisele Belusso

Universidade de Caxias do Sul - Brasil

Terciane Ângela Luchese

Universidade de Caxias do Sul - Brasil

\begin{abstract}
Resumo: O objetivo do presente artigo é narrar, a partir de um caderno de memórias, a história de vida da professora Maria Mocelini, nascida na Itália em 1878, imigrante e que se dedicou à profissão docente no Rio Grande do Sul como servidora pública estadual, de 1907 a 1939. Aposentada, viveu junto à comunidade das Irmãs Scalabrinianas no Colégio Nossa Senhora de Lourdes em Farroupilha/RS, até seu falecimento. $\mathrm{O}$ corpus empírico foi constituído pelo caderno de memórias manuscrito produzido pela professora Maria Mocelini e por outros documentos como narrativa de história oral, jornais, relatórios e fotografias. A metodologia foi a análise documental histórica e a história oral. O aporte teórico foi auferido pela História Cultural e História da Educação. Como resultado, é possível afirmar que a professora "inventou seu cotidiano" na escrita de seu caderno, tematizando a família, a profissão docente e as vivências junto à comunidade das Irmãs Scalabrinianas, deixando assim escritas de si que conformam uma identidade - a de docente pública, dedicada à educação e católica.
\end{abstract}

Palavras chave: Docência. Identidade. Memórias autorreferenciais.

\begin{abstract}
The purpose of this article is to narrate, from a memoir notebook, the life history of Maria Mocelini, teacher, born in Italy in 1878, immigrant dedicated to the teaching profession in Rio Grande do Sul, as a public employee of this state, from 1907 to 1939. She was retired, and lived within the community of Scalabrinian Sisters at Nossa Senhora de Lourdes School in Farroupilha/RS, until her death. The empirical corpus was constituted by her hand-written memory notebook, produced by Maria Mocelini, and by other documents as oral history narrative, newspapers, reports and photographs. The methodology was historic document analysis and oral history. Theoretical contribution was obtained by Cultural History and History of Education. As a result, it is possible to affirm that the teacher "invented her daily life" in the writing of her notebook, focusing on the family, the teaching profession and the
\end{abstract}


experiences with the community of the Scalabrinian Sisters, thus leaving writings for the self which make up an identity - that of the catholic, public teacher, dedicated to education.

Keywords: Teaching. Identity. Self-referenced Memories.

Resumen: El objetivo de este artículo es narrar, a partir de un cuaderno de memorias, la historia de vida de la profesora Maria Mocellini, en Italia, en 1878, inmigrante, que se dedicó a la profesión docente en Rio Grande do Sul como funcionaria pública de ese estado, de 1907 a 1939. Jubilada, vivió junto a la comunidad de las Hermanas Scalabrinianas en el Colegio Nuestra Señora de Lourdes en Farroupilha/RS, hasta su fallecimiento. El corpus empírico fue constituido por el cuaderno de memorias manuscrito producido por la profesora Maria Mocelini y por otros documentos como narrativa de historia oral, periódicos, informes y fotografías. La metodología utilizada fue el análisis documental histórico y la historia oral. El aporte teórico se obtuvo de la Historia Cultural y la Historia de la Educación. Como resultado, es posible afirmar que la profesora "inventó" su cotidiano" en la escrita de su cuaderno, trayendo los temas de la familia, la profesión docente y las vivencias junto a la comunidad de las Hermanas Scalabrinianas, dejando, de esta manera, escritas de sí que conforman una identidad- la de docente pública, dedicada a la educación y católica.

Palabras clave: Docencia. Identidad. Memorias autorreferenciales.

\section{Considerações iniciais}

"Relação Magnífica da professora Maria Mocelini e pais ao Brasil, muito agradecemos esse povo gentil!" (MOCELINI,[1939-1961],p.1)

No interior de arquivos, na construção da empiria, tão usual ao historiador da educação, emerge a proposta do presente artigo. A partir de um caderno encapado com papel vermelho, um manuscrito que há décadas permanecia em meio ao conjunto de atas e outros documentos da escrituração escolar do acervo do Colégio Nossa Senhora de Lourdes ${ }^{1}$, situado em Farroupilha, Rio Grande do Sul. O inesperado ali residia, naquela materialidade agora em mãos de historiadoras da educação, que com olhares inquiridores lhe dirigimos perguntas, que não se bastam pelo inédito ou pelo extraordinário, mas pelo ordinário que foi preservado. O manuscrito está intitulado “Documento Importante! Uma Biografia de Dona Maria Mocelini" um achado

\footnotetext{
${ }^{1}$ O Colégio Nossa Senhora de Lourdes pertence à Associação Educadora São Carlos (AESC) da Congregação das Irmãs Missionárias de São Carlos Borromeo Scalabrinianas. Foi fundado em 1917, em Farroupilha/RS, como uma instituição privada, confessional para atender meninos e meninas no Ensino Primário. A administração da instituição ficava a cargo das religiosas da Congregação, bem como a docência. Ver mais em Belusso (2016).

${ }^{2} \mathrm{O}$ sobrenome da professora foi escrito por ela Mocelini, com apenas uma letra "L", já nos jornais e outros documentos acessados, tais como sua nomeação, foi possível perceber que a escrita foi Mocellini, com duas letras "L". Por tratar das questões de identidade, manteremos no decorrer da escrita a grafia utilizada nas escritas ordinárias da professora Maria.
} 
com vinte páginas manuscritas ${ }^{3}$, repleto de vestígios que remetem à história de vida de uma mulher imigrante que se constituiu professora e se dedicou a vida para a docência.

Ao longo da narrativa, assim como podemos observar na epígrafe, a professora refere a si mesma e a sua relação com os pais e o país, no caso o Brasil, agora pensado como um caderno que constitui memória autorrefencial (VIÑAO FRAGO, 2000) ou um ego-documento ${ }^{4}$. A escrita foi em letra cursiva, desenhada e um pouco trêmula na última página do caderno. Não foi datada, porém traz elementos de um longo período, por diversas décadas e é provável que tenha sido escrito nos últimos anos de vida da professora, ou ainda, após a sua aposentadoria.

Não é possível sermos exatas na datação, mas pela análise consideramos que essas escritas ordinárias tenham sido realizadas entre 1939, quando ela passou a residir junto às Irmãs Scalabrinianas, até 1961, ano de seu falecimento. Pela estrutura de organização as quais apontamos como: nascimento, família, profissão e vivências junto à comunidade das irmãs, não poderemos deixar de afirmar que tal organização lembra as fichas de apostolado das religiosas dessa congregação, contudo, nesse caso, registrado em um caderno de escritas ordinárias compondo uma literatura autorreferencial (VIÑAO FRAGO, 2000).

Ao encontrar o caderno, fomos tomadas pelo encantamento, tentando compreender qual a atuação a professora Maria Mocelini tivera no Colégio Nossa Senhora de Lourdes, pois dada a representação (CHARTIER, 2002) de "importância" atribuída à ela, interpretamos, naquele momento, que ela poderia ter auxiliado de alguma forma aquela instituição. Na medida em que se avançava na pesquisa fomos percebendo que a professora Mocelini não atuou como docente naquela instituição.

Cientes de que a escrita autorreferencial tem um duplo sentido, ou seja, uma escrita privada vista como os "refúgios do eu", que pode vir a ser lida por outros leitores e que tais leitores podem constituir um campo de estudo específico, nos apropriamos das escritas ordinárias de Mocelini para análise, tornando-as públicas e transformando-as em "refúgios de todos" (VIÑAO FRAGO, 2000). Para tornar possível a análise da vida da mulher imigrante, católica, professora pública e que morou junto às Irmãs Scalabrinianas nos últimos anos de sua vida, mobilizamos diversos documentos, mas consideramos que o caderno constituiria a fonte principal da análise, posto que a partir dele e com ele, nos debruçamos a investigar e a narrar a história de vida da docente Maria Mocelini.

\footnotetext{
${ }^{3}$ As páginas foram numeradas pelas autoras.

${ }^{4} \mathrm{O}$ termo ego-documento foi cunhado em fins de 1958 por Jacob Presser, um historiador holandês, com o intuito de denominar a "diversidade de formas de expressão escrita dos sentimentos e experiências pessoais" (AMELANG, 2005, p. 17). Para Cunha (2019, p. 135) se trata de "textos em que um autor ou autora escreve, por si mesmo ou por intermédio de outro, sobre suas vivências (diretas ou conhecidas), sentimentos, pensamentos".
} 
Depois de decorrido um tempo na análise desse contexto, de escrita sobre o processo histórico do Colégio Nossa Senhora de Lourdes, voltamos a olhar para essas escritas ordinárias e questionamos: quem foi a professora Maria Mocelini? Qual seu envolvimento nessa comunidade e com essa congregação? Como ela foi morar junto à comunidade das Irmãs Scalabrinianas? Ela passou a dar aulas nesse colégio? Quais nuances da história de vida da professora, da imigrante e da mulher são possíveis pensar a partir de suas escritas autobiográficas?

A partir desses questionamentos, traçamos como objetivo perceber vestígios acerca da história de vida, da imigrante e da professora, Maria Mocelini ${ }^{5}$, dedicada exclusivamente à profissão docente no Rio Grande do Sul, como servidora pública estadual, de 1907 a 1939 e sua inserção na comunidade das Irmãs Scalabrinianas, junto ao Colégio Nossa Senhora de Lourdes após a sua aposentadoria. O corpus empírico foi o caderno manuscrito, além de narrativa de história oral, relatório, jornais e fotografias. Tais documentos foram analisados, categorizados e subsidiam a análise apresentada neste artigo. O estudo insere-se no campo da História da Educação, com ênfase nas histórias de vida de docentes, tendo como aporte teórico o diálogo entre História Cultural e História da Educação. Deste modo, a noção de documento entendido como produção humana e as "memórias e autobiográficas" (VIÑAO FRAGO, 1995, p. 67) ganham destaque para pensarmos a educação em diferentes temporalidades. Na metodologia, utilizamos a análise documental histórica e a história oral. Mobilizamos uma entrevista que foi gravada, transcrita e analisada a partir das memórias da Irmã carlista Mafalda Seganfredo. Extraímos da entrevista os trechos que eram significativos para situar a relação da professora Maria e o Colégio Nossa Senhora de Lourdes. Os demais documentos - jornais, fotografias, relatórios, registro no Livro de Tombo e caderno - foram digitalizados, seu conteúdo lido e categorizado. A partir deste movimento, foram selecionados os trechos mais significativos apresentados ao longo da narrativa. Também privilegiamos apresentar algumas das páginas do caderno escrito pela professora Maria, nosso documento principal, para que o leitor possa acompanhar e perceber a materialidade, bem como os registros que mobilizam nossa análise. Nos inspiramos, teoricamente, no que propõe Chartier (2002a, p. 61-62) ao afirmar que os “textos não estão fora dos materiais de que são veículos. Contra a abstração dos textos, é preciso lembrar que as formas que permitem sua leitura, sua audição ou sua visão participam profundamente da construção de seus significados".

\footnotetext{
${ }^{5}$ Ainda referente ao sobrenome era originalmente Mocelin, “como havia muitas famílias Mocelin, acrescentou-se [a letra] i e ficou reconhecido por Mocelini, atestado (sic) pelas autoridades." (MOCELINI, [1939-1961], p. 2).
} 
Mignot, Bastos e Cunha (2000) afirmam que "trazer à discussão o universo textual autobiográfico de mulheres constitui-se uma possibilidade" importante e singular, pois são raros os relatos e as histórias de vida de imigrantes-mulheres, que atuaram como docentes públicas e que produziram documentos tais como este privilegiado na análise, preservado no tempo. Compreendemos que o universo textual autobiográfico engloba literatura autorreferencial, que pode ser considerado um dos modos de constituir uma escrita autobiográfica e de memórias. Desta maneira, intentamos, com essa análise, contribuir para compreender algumas das representações possíveis da história de vida da professora Maria Mocelini.

O caderno, outrora, objeto da cultura material escolar, neste caso, foi suporte de uma escrita de si, de representações da vida da uma professora. O que motivou a escrita? Como afirma Sarlo "o discurso da memória, transformado em testemunho, tem a ambição da autodefesa; quer persuadir o interlocutor presente e assegurar-se uma posição no futuro" (SARLO, 2007, p. 51), ao fazê-lo, intenta preservar a história da sua vida, do quer que seja lembrado. Tais representações precisam ser consideradas, partilhadas e construídas pelos sujeitos para explicar o mundo, realizadas através do imaginário que comporta crenças, mitos, representações e constroem identidades (PESAVENTO, 2008). Como nos alerta Artières (1998, p. 31) “o arquivamento do eu não é uma prática neutra; é muitas vezes a única ocasião de um indivíduo se fazer ver tal como ele se vê e tal como ele desejaria ser visto". O caderno escrito por Maria Mocelini, no que tange sua materialidade, apresenta 20 páginas, numa brochura com $14 \mathrm{~cm}$ de largura e $21 \mathrm{~cm}$ de altura, encapado com papel vermelho. Sobreposto, na capa, uma colagem com papel mais claro em que consta a escrita Documento importante! Autobiografia de Dona Maria Mocelini. Todas as páginas disponíveis estão preenchidas com manuscritos que se alternam entre memórias e transcrições de documentos. As memórias foram por ela intituladas, dando um tom temático ao conjunto de lembranças, e compondo uma linearidade cronológica por ela elencada. Os títulos e uma síntese dos aspectos apresentados no caderno estão sistematizados no quadro a seguir.

Quadro 1 - Títulos das escritas de Maria Mocelini

\begin{tabular}{|c|c|}
\hline Títulos & Aspectos narrados/documentos transcritos \\
\hline 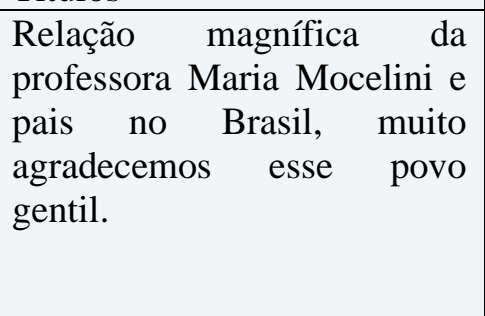 & $\begin{array}{l}\text { Seu nascimento, familiares (pais, avós e irmãos), vinda da Itália para } \\
\text { o Brasil, vivências no Rio Grande do Sul. Transcreve os seguintes } \\
\text { documentos: a nomeação para o cargo de professora estadual (1907); } \\
\text { um fonograma dela para o Bispo Dom João Becker pedindo orações } \\
\text { pela mãe agonizante (sem data) e a carta de Dom João Becker } \\
\text { parabenizando os pais de Maria Mocelini pelas bodas de casamento } \\
\text { (1921). }\end{array}$ \\
\hline
\end{tabular}




\begin{tabular}{|c|c|}
\hline Relação de efetivo serviço & Vida profissional. \\
\hline $\begin{array}{l}\text { O ramo da minha vida foi } \\
\text { lindo }\end{array}$ & Síntese dos municípios em que trabalhou. \\
\hline Nota do meu estudo escolar & Seu processo de escolarização. \\
\hline $\begin{array}{l}\text { O último extremo do } \\
\text { falecimento da mamãe, vi-me } \\
\text { aflita. }\end{array}$ & $\begin{array}{l}\text { Nomina as famílias que ofertaram recebê-la ou auxiliá-la e explica } \\
\text { da sua decisão de morar com as irmãs. }\end{array}$ \\
\hline $\mathrm{O}$ arrimo feliz & $\begin{array}{l}\text { A vivência com as irmãs, cita novamente o falecimento do pai e da } \\
\text { mãe. }\end{array}$ \\
\hline $\begin{array}{l}\text { O meu aniversário de } 80 \text { anos } \\
\text { de idade }\end{array}$ & $\begin{array}{l}\text { Conta da celebração que aconteceu no Colégio Nossa Senhora de } \\
\text { Lourdes. }\end{array}$ \\
\hline Data alegre & $\begin{array}{l}\text { Suas práticas cotidianas e a celebração em honra aos } 50 \text { anos de } \\
\text { professora. }\end{array}$ \\
\hline Trabalho de ensino & $\begin{array}{l}\text { O que ensinava em aula. Cita ao final sem mencionar sobre a menina } \\
\text { Angelina, uma órfã que o pai acolheu e ficou por dez anos com eles. }\end{array}$ \\
\hline
\end{tabular}

Fonte: Quadro elaborado pelas autoras a partir do caderno da professora Maria Mocelini ([1939-1961]).

Cientes de que a construção de si, por meio da cultura escrita, agrega diversos modos, consideramos que ao apropriar-se de um suporte para a escrita e munida de uma caneta, aquela que escreve, o faz no intuito de "arquivar sua vida" (ARTIÈRES, 1998). Ao registrar, inventa um cotidiano (CERTEAU, 1994), nostalgicamente lembra de algumas histórias, organiza memórias que são, ao mesmo tempo, individuais e coletivas (HALBWACHS, 2006). Essa escrita, estreitamente vinculada aos pertencimentos étnicos e culturais, com lembranças e esquecimentos (POLLAK, 1998), coloca a autora como referência dessa escrita (VIÑAO FRAGO, 2000), constituindo identidade(s) para si. Ao escrever sobre sua vida, torna o caderno um lugar de memória (NORA, 1993), de memória do vivido, que pode vir a ser lido por outros e constituir objeto investigativo. O modo de narrar-se da professora Maria Mocelini, subjetivado por ela em um contexto político, cultural, social, profissional, étnico e religioso, torna-se um dos possíveis modos de representar-se a si mesma em seu escrito.

\section{Professora Maria Mocelini: a seu modo, as escritas de si...}

"Nascida às 2 horas de manhã em 19 de novembro em 1878, distrito de Scio [Schio] Província de Vicenza, região setentrional. Veneto, batizada na igreja Arcipritale de Seio Curia Vesco vile Vicenza. Filha de Sebastião Mocelini e Antonia Lazzarotto. Avós Maternos Jacomo Lazzarotto e Antonio Gusso. Avós Paternos Baldissera Mocellin e Antonia Batistini. Pai nascido em S. Mario. A Mãe nascida em Valstagna. Ambos na cidade de Bassano, província de Vicenza, Região Setentrional 
No ano de nascimento de Maria Mocelini, avolumavam-se os emigrados que partiam da península itálica em direção à diversos destinos, inclusive para o Brasil. A maior parte dos que emigraram e se estabeleceram no Rio Grande do Sul entre os anos de 1875 e 1914 saíram do Vêneto (TRENTO, 1989; FRANZINA, 2006). E no Vêneto, convulsionado por mudanças sociopolíticas e econômicas, que a família Mocelin resolve emigrar. Maria contava com 13 anos de idade. Os antecedentes familiares, dentre outros, são temas centrais no início de um bom número de escritas autobiográficas e memórias (VIÑAO FRAGO, 2000a). Nesse tocante, utilizamos a escrita da professora Maria Mocelini que, já na epígrafe, anuncia seu nascimento, filiação, avós maternos e paternos e também o local de nascimento de seus pais.

Seu pai foi construtor na Itália, vieram para o Brasil por motivos de saúde da mãe de Maria, aconselhados por "doutores e sacerdotes" e não retornaram mais para seu país de origem. Em seus manuscritos, Maria registra a justificativa declarada pela mãe: “[...] si nossos filhos ressucitassem, sim voltaria, mas eles não ressucitam mais, por isso ficamos aqui, estamos bem com as autoridades, nos querem e a nossa filha está estudando para ser professora um dia". A filha referida é Maria Mocelini (MOCELINI, [1939-1961], p. 3). Já seus irmãos, faleceram em solo brasileiro “[...]todos pequeninhos de 3, 2, 1 ano, em número de 13” (MOCELINI, [19391961], p. 4). É visível que a família sofreu perdas sucessivas, permanecendo apenas Maria Mocelini, dentre os filhos nascidos e vivos.

Essa família, como tantas outras, emigra da Itália para o Brasil, desembarcando na Província de São Pedro do Rio Grande do Sul e, posteriormente, deslocando-se para a encosta superior do Nordeste. O que ocorreu em um número significativo, em termos de chegada de imigrantes italianos, a partir a partir de 1875 (LUCHESE, 2015, p. 15). Na narrativa, Maria conta que

Saímos da Itália em 8 de abril de 1891, chegamos em Porto Alegre e fomos morar no Menino Deus [bairro] logo que chegamos fomos agradecer à Jesus da boâ viagem, recebemos a santa comunhão com a missa. O papai logo de chegada encontrou serviço. Foi administrador do asilo dos mendigos e collegio de orfãs de Santa Tereza do falecido Padre Cacique de Barros. As autoridades entregaram a meu pai inúmeras famílias para guiá-los e protêgelos. Mais tarde ele foi mestre do quartel militar do Menino Deus e do Cristal em Porto Alegre e em várias outras construcções. (MOCELINI, [1939-1961], p. 4).

Neste excerto, podemos auferir que a família vive os primeiros anos na capital, Porto Alegre. Católicos, a vinculação religiosa da família com a Igreja é destacada, porque Maria se preocupa em registrar o agradecimento a Jesus pela boa viagem. Além disso, observa-se que o pai da professora também teve uma vinculação com a educação trabalhando no asilo de 
mendigos e Colégio de Orfãos Santa Tereza. O pai, Sebastião Mocelini, naturalizou-se brasileiro e alistou-se como eleitor em 1902, aos 55 anos (Jornal ‘A Federação’, 04/08/1902, p. 4).

Assim como na epígrafe, nessas primeiras páginas de escritas de si, a família mereceu destaque, afinal, pois registrou sobre os irmãos falecidos, a atuação profissional do pai e a saúde frágil da mãe. Além de informar o nome de seus familiares - pais e avós, e dos locais de nascimento. A professora Maria destacou também uma ocasião festiva relacionada aos seus pais. O registro é breve, mas significativo da sociabilidade vivida, do cuidado e do acompanhamento de Maria Mocelini para com seus pais.

A celebração registrada foi as bodas de cinquenta anos de casados, comemoradas em Farroupilha. Ocasião em que os pais receberam uma carta do arcebispo Dom João Becker em 9 de maio de 1921. Ela transcreveu a carta minuciosamente em suas memórias, denotando a importância dada por ela para a correspondência e, mais uma vez, evidenciando a relação da família com a Igreja Católica. A representação presente no registro atribui destaque e evidencia o sentido de valor da correspondência do bispo, bem como da relevância das práticas do catolicismo no convívio familiar.

Ao tratar de seu processo de escolarização e formação para docência aponta que:

Quando cheguei da Itália estava na 3aㅗ classe, logo entrei na aula Pública do estado do Rio Grande do Sul depois entrei pensionista no Colegio das Orfãns do Reverendo Padre Cacique de Barros em Porto Alegre e lá fiquei 4 anos a mais. Depois entrei na Escola Complementar de Porto Alegre, até que terminei o primeiro ano, e ahi fecharam a escola e eu continuei estudar particularmente com o Senhor Professor Emilio Henrique Meyer até entrar em concurso em que fui nomeada professora em 16 de fevereiro de 1907 (MOCELINI, [19391961], p.11).

A menina imigrante já tinha tido experiências escolares na Itália. No Brasil, sua escolarização ocorreu em espaços públicos e confessional, chegando a frequentar a Escola Complementar. Interessante destacar que a interrupção na frequência à Escola Complementar não impediu sua nomeação para a docência, visto que concluiu os estudos com aulas particulares com o Professor Emilio Meyer. Maria Mocelini prestou concurso para professora estadual e foi nomeada em 1907. O documento de nomeação é o último no conjunto dos que são transcritos pela professora, como podemos ver na figura a seguir: 
Figura 1: Nomeação Maria Mocelini - 1907

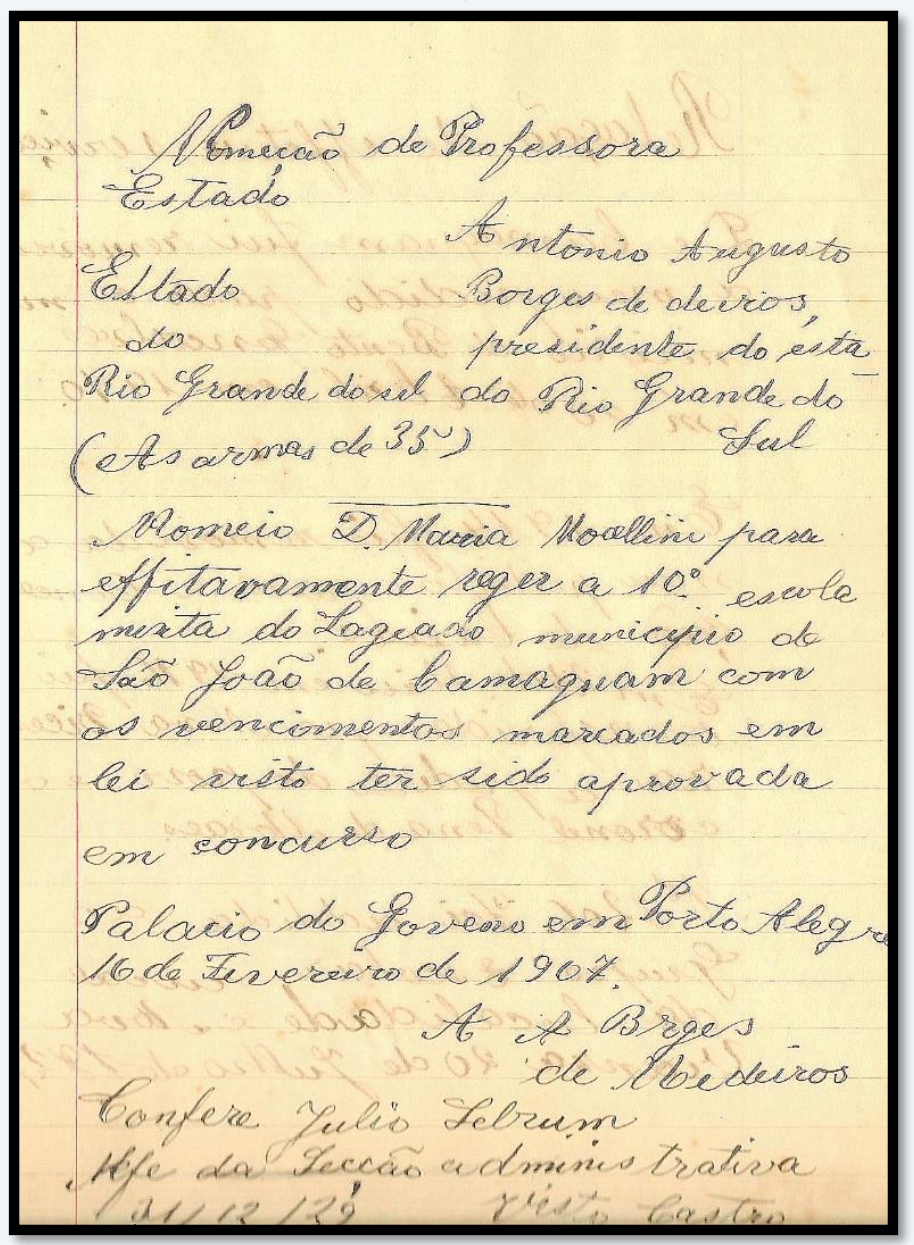

Nomeação da Professora Estado.

Antonio Augusto Borges de

Medeiros, presidente do estado do Rio Grande do Sul. Estado do Rio Grande do Su ( As armas de 35). Nomeio D. Maria Mocellini para effetivamente reger a $10^{\mathrm{a}}$ escola mista do Lageado município de São João de Camaquam com os vencimentos marcados em lei visto ter sido aprovada em concurso. Palacio do Governo em Porto Alegre, 16 de fevereiro de 1907. A. A. Borges de Medeiros. Confere Julio Lebrun. Chefe da Secção administrativa 31/12/29 - Visto Castro.

Fonte: Mocelini [1939-1961], p. 7.

De Camaquã, a docente foi transferida devido ao seu pedido para Bento Gonçalves em 20 de abril de 1910, e em 1914 para Caxias. Sua estada em Caxias pode ser localizada pela menção nos jornais. Em 1915, em anúncios sucessivos foi publicado o aviso a seguir:

Aviso. A aula do curso elementar superior da Conceição (Caxias) se abrirá no dia $1^{\circ}$ de março do corrente ano de 1915. As matérias compreendem as seguintes: português, matemática, aritmética, geometria, geografia geral, história, escrituração mercantil, canto escolar, desenho, línguas francês e italiano. A pensão mensal $\mathrm{I}^{\circ}$ ano $5.000 \mathrm{II}^{\circ}$ ano $10.000 \mathrm{e} \mathrm{III}{ }^{\circ}$ ano 15.000 . As lições são de tarde, das 2 às 4 nas segundas-feiras, quartas ou sábados. A professora, Maria Mocellini. (Jornal Cittá di Caxias, 15/02/1915, p. 2).

Além de professora pública estadual, Maria atuava como professora particular em dias específicos e também recebendo pensionistas. As matérias de ensino, como informado no jornal, incluíam a escrituração mercantil - conhecimento valorizado para aqueles que atuariam no comércio. Além disso, chama atenção para o ensino de línguas como o italiano e o francês. 
Em 1916, o anúncio é novamente apresentado, mas não constam os custos e nem o horário das aulas.

\begin{abstract}
Aviso. A professora pública Maria Mocellini avisa ao público que no dia $1^{\circ}$ de março começam as aulas do curso elementar superior. As matérias deste curso compreendem as seguintes: português, matemática, aritmética, álgebra, geometria, geografia, história, escrituração mercantil, canto escolar, desenho, línguas francês e italiano, história natural. Conceição, Caxias (Jornal Cittá di Caxias, 24/02/1916, p. 5).
\end{abstract}

Outro indício documental que nos permite pensar que a professora Maria Mocelini foi reconhecida e elogiada, é evidenciado pelos resultados obtidos nos processos avaliativos de seus alunos. Ela foi representada como competente e ótima professora, o que afirmavam em 1915, conforme o excerto:

Em 4 de dezembro, os numerosos escolares da Conceição - na qual é docente a distinta senhorita Maria Mocellini - foram realizados os exames finais. O brilhante resultado mostrou à comissão examinadora a ótima preparação das alunas e dos alunos, louvando os esforços da professora para a obtenção dos brilhantes resultados (Jornal Cittá di Caxias, 21/12/1915, p. 07 - tradução nossa) ${ }^{6}$.

Em 24 de maio de 1916 foi novamente transferida, para Nova Vicenza ${ }^{7}$, permanecendo até a aposentadoria. Nas memórias consta que "a pedido do povo e do Coronel Pena de Moraes", em 20 de julho de 1927, passou a atuar no Grupo Escolar rural daquela localidade (MOCELINI, [1939-1961], p. 8). O que também pode ser constatado no estudo de Fernandes (2015) acerca do Grupo Escolar Farroupilha, instituição em que a professora atuou, como pode ser observado no trecho a seguir:

\begin{abstract}
Sua história no magistério farroupilhense inicia em 24 de maio de 1916, quando assume a regência da $22^{a}$ Aula Púbica e Mista de Nova Vicenza e depois do grupo escolar, permanecendo na instituição aproximadamente até o final da década de 30 do século XX. No ano de 1932, é jubilada ao completar vinte e cinco anos de magistério estadual, sendo, em 1938, promovida por antiguidade à categoria de $3^{\mathrm{a}}$ entrância, continuando a exercer a profissão no grupo escolar até meados de 1939, quando há vestígios que teria se aposentado e permanecido até o seu falecimento nas dependências da Escola Nossa Senhora de Lourdes em Farroupilha (FERNANDES, 2015, p. 94).
\end{abstract}

\footnotetext{
${ }^{6}$ No original "Il 4 dicembre, la numerosa scolaresca della Conceição - della quale é docente la distina Sinorina Maria Mocellini dette gli esami finali. Il brillante risultato mostro alla comissione esaminatrice la ottima preparazione delle alunne e degli alunni i lodevoli sforzi della maestra per raggiungere sì brillanti risultati" ((Jornal Cittá di Caxias, 21/12/1915, p. 7).

${ }^{7}$ Consta nota em jornal afirmando que "Magistério público - a professora D. Maria Mocellini foi removida da 24 escola mista de Conceição para a $22^{a}$ também mista, de Nova Vicenza, ambas no município de Caxias, e desta para aquela, a professora D. Sylvia de Freitas Faria” (Jornal ‘A Federação’, 24/05/1916, p. 6). Em 1934 os distritos de Nova Vicenza, Nova Milano, Nova Sardenha e Vila Jansen tornam-se o município de Farroupilha em virtude da emancipação política.
} 
Ao tomar a pesquisa de Fernandes (2015), apontamos a exatidão das datas citadas pela professora em suas memórias autorreferenciais, o que pode indicar que, apesar de não transcrever literalmente os documentos, é provável que Maria Mocelini os tenha usado como consulta para dar exatidão às informações que produzia. Ainda, como representações do trabalho desenvolvido em Farroupilha - na época Nova Vicenza, distrito de Caxias - como docente, em publicação de jornal, constam os resultados finais dos exames da aula da professora Maria, sendo exaltado, novamente, o seu fazer:

I Curso elementar inferior. Oreste Dalle Molle - português 10, aritmética - 10, geometria 10 , geografia -10 , história pátria -10 , história natural -9 , desenho - 10. Paulo Panazzolo - português - 10 , aritmética - 10, geometria - 10, geografia -8 , história pátria -9 , história natural -8 , desenho -9 . Maria Dal Molin e Ernestina Getter - grau 9. Assumpta Antonello e Almerinda Perottoni - grau 8. Pedro Côrte e Carolina Tartarotti - grau 7. Olga Tartarotti e Olivia Amaral - grau 6,5. Albino Fetter e Paulino Belissimo - grau 6. Cujos examinadores foram Dr. Adriano N. Moré, presidente da mesa examinadora.Pe. Luiz Segale - vigário; Guilherme Tartarotti, Abramo Dal Molin, Umberto Jaconi e João Frederico Fetter (ouvintes). Maria Mocelini, professora pública. $2^{\circ}$ exame - do $2^{\circ}$ curso elementar superior - $\mathrm{o}$ aluno Oreste Dalle Molle mereceu em português, aritmética, geografia, geometria, história pátria, história natural, noções de civismo - distinção. Paulo Panazzolo - não compareceu. Maria Dal Molin - grau 8; Ernestina Fetter - grau 8,5; Almerina Perottoni - grau 7; Assumpta Antonello - grau 6. Cujos examinadores foram Dr. Adriano N. Moré, presidente da mesa examinadora, José Generosi, sub intendente, Arthur Perottoni, Guilherme Tartarotti. Maria Mocelini. Professora pública. Nota do redator - $\mathrm{O}$ 'Cittá di Caxias' congratula vivamente a distinta e comprovada mestra senhora Maria Mocelini, e com seus bons estudantes pelo brilhante êxito obtido nas provas finais de 1916 (Jornal Cittá di Caxias, 08/01/1917 p. 2).

A representação da professora zelosa, dedicada e com bons resultados nos exames finais, resume-se a alguns dos estudantes, pois segundo as informações dos relatórios da intendência, o número de alunos atendidos era bem superior ao que foi publicado como resultado nos exames finais ${ }^{8}$. Foi possível localizar referências dos anos de 1915, 1916, 1917, 1925 e 1926 relacionadas à localização da escola em que a professora Maria Mocelini lecionou, bem como o número de alunos matriculados e frequentes das aulas mistas, conforme o quadro a seguir:

\footnotetext{
${ }^{8}$ No ano seguinte, outra matéria foi publicada novamente: "Resultado do exame final de Nova Vicenza de 1917. Primeira classe, Pedro Antonello e Eugenio Dal Molin. Segunda Classe. Distinção. Carolina Tartarotti, 10. Herminia Felippi, 9. Angelina Felippi, 10. Olga Tartarotti, 8. Germano Puhl, 8. Ottilia Maggioni, 7. Terceira classe. Augusto de Oliveira, 9. Celita Fetter, 9. Adelia Tartarotti, 9. Isabel Milesi, 7. Olga Piccoli, 7 e mais as alunas Palmyra Corte e Paulina Noro aprovadas com melhoria de classe. Os outros alunos prestaram exercícios de leitura, contas, numeração, escrita, em que foram também classificados, distinguindo-se entre eles. Henrique Gomes e Constantino Gomes. Maria Mocelini. Professora pública”. (Jornal Cittá di Caxias, 05/01/1918, p. 3).|
} 
Quadro 2 - Alunos e locais das aulas da professora estadual Maria Mocelini

\begin{tabular}{|c|c|c|c|c|c|c|c|c|}
\hline Ano & Local da aula & Tipo de escola & \multicolumn{3}{|c|}{ Matriculados } & \multicolumn{3}{c|}{ Frequentes } \\
\cline { 4 - 9 } & Masc. & Fem. & Total & Masc. & Fem. & Total \\
\hline 1915 & Conceição, Caxias & Aula mista & 45 & 36 & 81 & 21 & 18 & 40 \\
\hline 1916 & $\begin{array}{c}\text { Nova Vicenza } \\
\text { (Estação) }\end{array}$ & Aula mista & 35 & 31 & 66 & 26 & 16 & 42 \\
\hline 1917 & $\begin{array}{c}\text { Nova Vicenza } \\
\text { (Estação) }\end{array}$ & Aula mista & 35 & 31 & 66 & 26 & 16 & 42 \\
\hline 1925 & $\begin{array}{c}\text { Nova Vicenza } \\
\text { (Estação) }\end{array}$ & Aula mista & 22 & 20 & 42 & 17 & 17 & 34 \\
\hline 1926 & $\begin{array}{c}\text { Nova Vicenza } \\
\text { (Estação) }\end{array}$ & Aula mista & 38 & 27 & 65 & 28 & 20 & 48 \\
\hline
\end{tabular}

Fonte: Relatório dos Intendentes de Caxias, Arquivo Histórico Municipal de Caxias do Sul.

O quadro 1 permite perceber que a aula da professora Maria Mocelini era bem frequentada se considerarmos a época. Chama atenção também as comemorações cívicas que foram promovidas por ela em atendimento às orientações e às prescrições. Como exemplo, na transcrição a seguir, a divulgação da celebração da Semana da Pátria de 1917:

Nova Vicenza. 7 de setembro. Programa da festa realizada em Nova Vicenza na aula escolar. A passeata cívica, pelas principais ruas de povoação o Batalhão Infantil, assistido pela respectiva Professora. Cortejo das meninas e meninos, trajando vestes claras com faixas nas cores nacionais, desfraldando aos ventos de Nova Vicenza o auriverde pendão da nossa pátria. Hino à Pátria - canto. Discurso - Angelina Felippi. A bandeira - Ottilia Maggioni. O dia do Fico Angelina Felippi, Paulina Noro, Alzira Tartarotti. A coroação - Carolina Tartarotti, Angelina Felippi, Olga Tartarotti. Vivas - Celita Fetter. Hino do Brasil (canto). Carolina Tartarotti - Liberdade. Augusto de Oliveira - Minha pátria. Antonio Domingos Manos - Minha terra. Esquadrão 7 de setembro comandante Germano Pukl. Hino à Pátria 7 de setembro. Soneto 7 de setembro - Alzira Tartarotti. A Luz - Olga Tartarotti. A Instrução - Hermínia Felippi. A primavera - Isabel Milesi. Ao Brasil - Hermínia Pukl. As estações - Celita Fetter, Alzira Tartarotti, Paulina Nora, Antonia Bertuol. Preces da Infância Maria de Oliveira Pinto. Queridos colegas - Adelia Tartarotti. A dança infantil. Hino ao trabalho. Canto com harmônio. Exercícios - Ao Luar - Minha Pátria. Maria Mocellini, professora (Jornal Cittá di Caxias, 20/09/1917, p. 5).

Para tais festividades, a professora Maria Mocelini enviava correspondências para o intendente, o subintendente e outras autoridades locais, convidando-os a integrarem as atividades. E neste ínterim, localizamos evidências do posicionamento e das negociações políticas empreendidas pelos professores, no caso, pela docente Maria Mocelini. Um deles, do início de 1923 em que foi publicada a felicitação no Jornal 'A Federação' com os seguintes dizeres: "Envio meus sinceros parabéns pela vitória gloriosa dos republicanos. Maria Mocelini. Professora pública” (Jornal ‘A Federação', 30/01/1923, p. 5). Tal nota mostra o posicionamento público revelado pela professora num momento de disputas. As eleições tinham transcorrido 
em clima muito tenso na disputa de assistas e borgistas que ocasionou a Revolução de 1923, findada com o Tratado de Pedras Altas em dezembro daquele ano ${ }^{9}$. Uma década depois, em nota publicada e assinada coletivamente, há o apoio dos professores à permanência no poder estadual de Flores da Cunha.

Nova Vicenza, 9 - os funcionários estaduais de Nova Vicenza apelam a V. Ex. permanecer no governo do Estado para felicidade da classe que tanto tendes amparado para grandeza maior do nosso Rio Grande. Saudações cordiais. Antão Baptista, enólogo instrutor; Argeus Medeiros, chefe do Laboratório de Análises; Pedroso Job, diretor do Grupo Escolar; Jardelino Courtates, capataz da estrada; Dante Figueiredo, bromatologista; Arthur Comandulli, do laboratório; Candido Acauan, coletor estadual; Plínio Pinto Amando, guarda da exatoria estadual; Albertina Cibelli, professora do Grupo; Adelaide Costa Leite, professora; Yolanda Calasans, professora do Grupo; Maria Mocelini, professora do Grupo; Norma Vizeu, professora do Grupo; Severo Zambin, escrivão distrital (Jornal 'A Federação', 23/11/1933, p. 2).

A expressão pública do apoio de professores e de outros funcionários públicos estaduais não será aqui aprofundanda, mas é elemento para somar na composição dos fragmentos irregulares de uma vida ou do que dela se representa, no caso da professora Maria Mocelini. Então, após onze anos lecionando na escola da Estação Férrea e 12 anos no Grupo Escolar Farroupilha, em 1939, aposentou-se "sem ter uma licença" ( MOCELINI, [1939-1961], p. 9). O período em que ocorre a aposentadoria (1939), o que a professora destaca é que ao se aposentar nunca tirou uma licença, e outra citação feita por ela é: "por duas vezes assumi a direção do Grupo Escolar nos intervalos da nomeação de novos directores escolares" (MOCELINI, [1939-1961], p. 9). Tais escritas remetem à representação que a professora impunha a si, transparecendo compromentimento, responsabilidade e confiança. O indício de pesquisa de Fernandes (2015) pôde ser confirmado, de que a professora passa a residir junto às irmãs e, nesse momento, pudemos compreender de maneira mais próxima, a seu modo, em suas escritas de si.

Nas primeiras páginas de suas memórias, a professsora Maria Mocelini organizou suas lembranças por meio de escritas de si que remeteram, a seu modo, as representações de filha e de professora. A seguir, passamos para a análise de seu tempo de aposentadoria e a convivência na comunidade das Irmãs Scalabrinianas.

\footnotetext{
${ }^{9}$ Sobre a Revolução de 1923 no Rio Grande do Sul ver RECKZIEGEL e AXT, 2007.
} 


\section{Outro tempo: o de professora aposentada...}

\section{“O ramo da minha vida escolar foi lindo [...].Quando fui aposentada, acolhi-me no colegio das Irmãs de São Carlos e aqui estou vivendo." ( MOCELINI, [1939-1961], p. 10).}

A epígrafe anuncia o fim de um tempo e início de outro. Fim de um tempo "lindo" representado pela professora - aquele em que atuara como professora pública estadual e, posteriormente, o início do tempo de aposentadoria, como anunciado por ela. A aposentadoria que viveu como acolhida no colégio das Irmãs de São Carlos em Farroupilha ${ }^{10}$.

Para compreender as questões que levaram a esse desfecho é preciso voltar às escritas de Maria Mocelini para perceber que a professora tem sua aposentaria concedida após o falecimento da sua mãe ${ }^{11}$, e como nunca casou, residia sozinha. Não foi possível saber onde ela residia anteriormente e qual motivação gerou a necessidade de se mudar no momento de sua aposentadoria. $\mathrm{Ou}$, ainda, se a mudança foi motivada pela ausência de familiares próximos e pela falta de companhia. Notamos que a constante troca de residência foi descrito como um período de "dias aflitos” pela professora em suas memórias, apresentadas na íntegra nas figuras 2 e 3.

\footnotetext{
${ }^{10}$ Farroupilha foi emancipada em 1934 a partir de áreas territoriais dos municípios de Caxias, Bento Gonçalves e Montenegro. A área central era a sede do $2^{\circ}$ distrito de Caxias, conhecido e denominado como Nova Vicenza.

${ }^{11}$ O pai da professora Maria Mocelini faleceu em fevereiro de 1928. Conforme nota publicada "Em Nova Vicenza, sede do $2^{\circ}$ distrito deste município, faleceu, no dia 04 do corrente mês o Sr. Sebastião Mocellini, que contava 86 anos de idade e era natural da Itália. O extinto, que desfrutava amizade naquela sede, era casado com Dona Antonia Lazzarotto Mocellini, deixando uma filha, a professora Maria Mocellini. As cerimônias fúnebres estiveram muito concorridas, cobrindo o féretro grande quantidade de flores naturais" (Jornal O Regional, 13/02/1928, p. 2). Quanto ao falecimento da Mãe, Antonia Lazzatotto Mocelini não foram localizadas outras informações.
} 
Figura 2: Manuscritos Maria Mocelini [1939-1961]

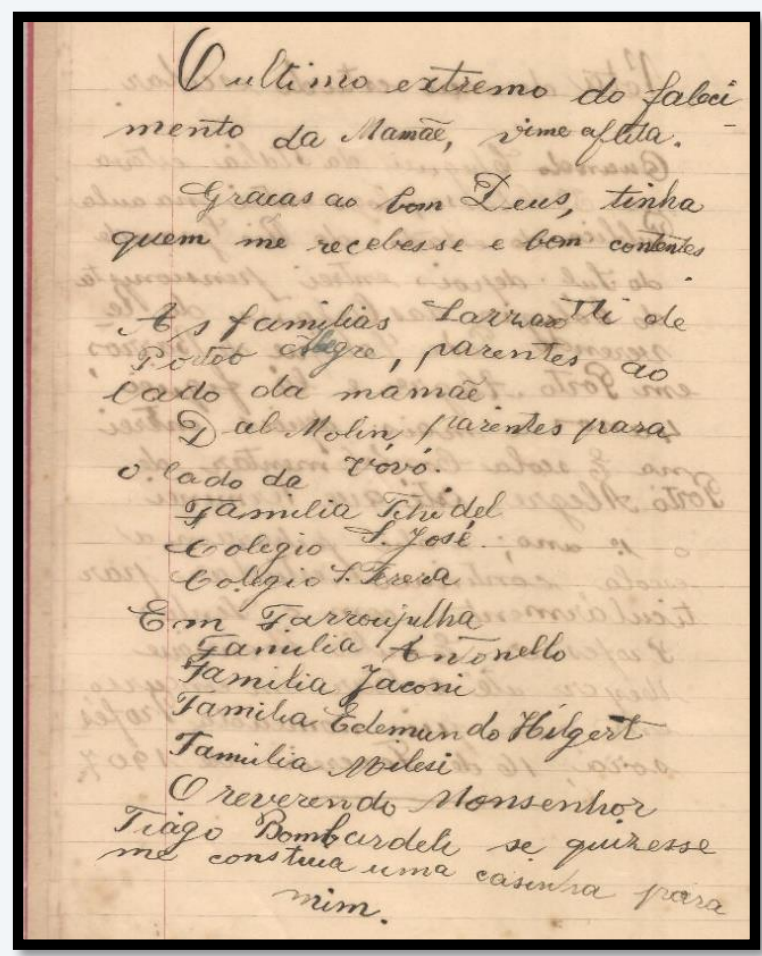

Fonte: Mocelini [1939-1961], p. 12.
O último extremo do falecimento da Mamãe, vi-me aflita.

Graças ao bom Deus, tinha quem me recebesse e bem contentes.

As famílias Lazzaretti de Porto Alegre, parentes do lado da mamãe.

Dal Molin parentes para o lado da Vovó.

Família Tchedel

Colégio São José

Colégio S. Tereza

Em Farroupilha

Família Antonello

Família Jaconi

Família Edemundo Hilgert

Família Milesi

O reverendo Monsenhor Tiago Bombardelli se quisesse me construía uma casinha para mim.

Figura 3: Manuscritos Maria Mocelini [1939-1961]

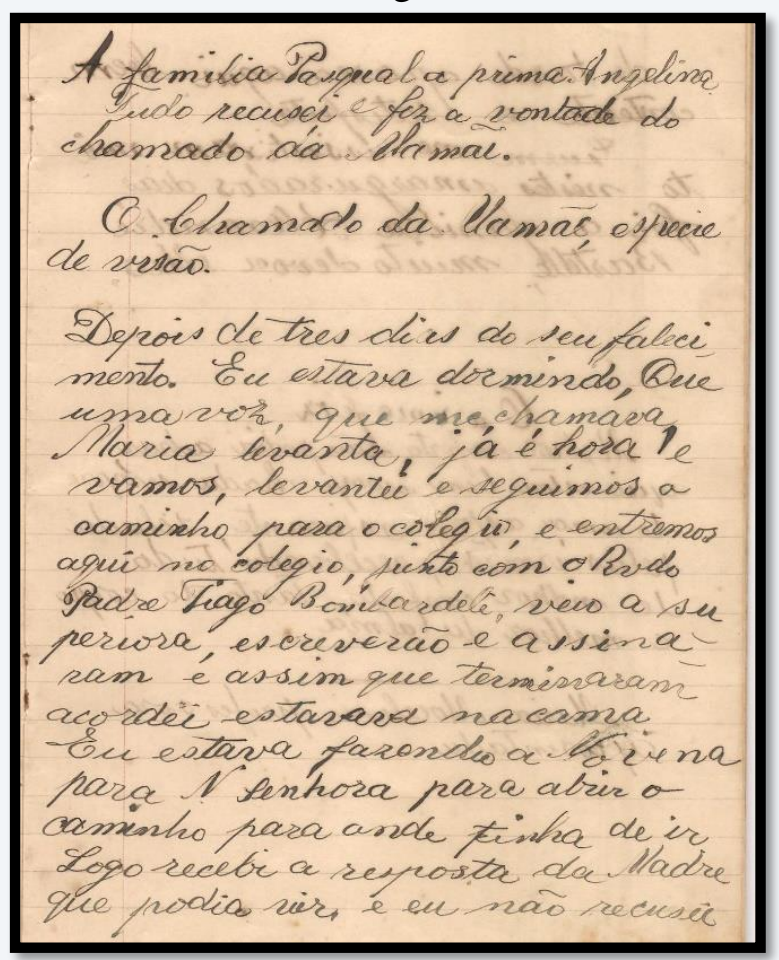

A família Pasqual a prima Angelina

Tudo recusei e fiz a vontade do chamado da Mamãe.

O Chamado da Mamãe, espécie de visão.

Depois de três dias do seu falecimento. Eu estava dormindo. Que uma voz que me chamava, Maria levanta, já é hora, e vamos, levantei e seguimos a caminho para o colégio e entremos aqui no colégio, junto com o Revdo. Padre Tiago Bombardelli, veio a superiora, escreverão (sic) e assinaram e assim que terminaram acordei, estava na cama.

Eu estava fazendo a Novena para N. Senhora para abrir o caminho para onde tinha de ir. Logo recebi a resposta da Madre que podia vir, e eu não recusei.

Fonte: Mocelini [1939-1961], p. 13. 
E a professora ainda registra "melhor conforto não podia encontrar, estou aqui bem acompanhada de uma aspirante, zelada pelas irmãs, recebendo tudo de melhor conforto, tanto do corpo quanto da alma." (MOCELINI, [1939-1961], p. 14). Apesar de se tratarem de duas imagens, figuras 2 e 3, optamos por apresentá-las na íntegra pela riqueza de percepções da professora em torno desse momento de vida. Ela novamente atribui a si uma representação de uma pessoa querida na comunidade e na família. Desejada e com ofertas de várias pessoas para ser acolhida. Nesta perspectiva, teria familiares e famílias da comunidade em Porto Alegre, local que a família viveu nos primeiros anos no Brasil. E, em Farroupilha, local onde atuou como professora até a aposentadoria, dispostas a acolhê-la ou como no caso do Monsenhor Tiago Bombardelli, auxiliá-la na construção de uma moradia, também no município de Farroupilha. O que reflete suas relações de sociabilidade tanto no município de Farroupilha como na capital do Estado.

Apesar dos convites, em “dias aflitos”, ela recorre a crença para tomar a decisão para onde iria e escreve quase uma experiência mística em que a mãe em um sonho lhe indicará o melhor caminho. A partir de então, quando do aceite da Madre Superiora da Congregação das Irmãs Scalabrinianas de São Carlos Borromeo, vai residir junto a essa comunidade. Descreve que se sentia contemplada em suas necessidades de "corpo e alma". Novamente, a representação do valor da sociabilidade em meio às práticas do catolicismo.

A professora Irmã Mafalda Seganfredo, religiosa da Congregação de São Carlos Borromeo Scalabriniana, conviveu com a professora aposentada Maria Mocelini e, ao ser entrevistada sobre o processo histórico do Colégio Nossa Senhora de Lourdes, recordou de uma de suas atribuições na instituição no período em que lá esteve, década de 1950, dentre elas, a de auxiliar a professora aponsentada.

É, então ela veio morar com as irmãs e as irmãs digamos, ela tinha o apartamentozinho dela né. [...] Mas ela não ficou sempre aí. Ela quando começou... porque ela tinha problema de espinha dorsal, que tinham feito uma injeção e ela ficou assim não se mantinha de pé, digamos sozinha sem um amparo, alguma coisa. Depois quando começou ser mais difícil pra ela tomar banho essas coisas, depois ela então passou dentro da comunidade das irmãs, no primeiro piso que tinha a entrada no Nossa Senhora de Lourdes, tinha a entrada e logo na entrada então tinha um apartamento... um apartamentozinho dela, então ela ficava ali e eu estava encarregada de cuidar dela (SEGANFREDO, 2015).

A narrativa de história oral, indica que no início ela tinha uma residência junto à escola, com certa autonomia, contudo, com o passar do tempo e o agravamento de suas condições de saúde, passou a viver em um espaço dentro do prédio escolar, junto com a comunidade das 
irmãs. Ainda no que tange ao cuidado com a professora, a Irmã Mafalda rememora aspectos cotidianos dessa convivência e cuidado.

Então onde tem uma irmã, quer dizer eu estou lá como gerente de uma turma que acompanhei até a quarta série, então eu estou lá, mas eu me chamava irmã Amantina. É, então ela gritava, irmã Amantina vem me dá banho! Muitas vezes eu tinha que dar jeito, me fazer substituir, pra dar banho. Depois ela perdia, as vezes também ela perdia o controle ela achava que não estava no quarto dela, não é? Então eu tinha que sair da aula e ia dava uma voltinha na portaria ia e disse pronto agora você. Ela dizia porquê que me levaram embora do meu quarto? Como fazem os velhinhos como se perdem, né? (SEGANFREDO, 2015, grifo nosso).

E assim, as irmãs, tal como Mafalda (nome religioso Amantina) agregavam as funções na escola com o cuidado à professora Maria Mocelini, repercutindo nas rotinas escolares. No entanto, foi algo verbalizado com carinho pela irmã Mafalda, não como um representação de algo que fosse um transtorno, o que indica que havia um comprometimento da congregação no cuidado com Maria Mocelini. A Irmã Mafalda registra em sua fala de que Maria Mocelini não foi professora no Colégio Nossa Senhora de Lourdes, contudo ela foi incluída de outras formas no cotidiano escolar, como na inauguração da Biblioteca da instituição, conforme convite transcrito no caderno da aluna Dulce Tartarotti, em 28 de março de 1940:

Temos a insigne honra de convidá-la para ir assistir a inauguração de nossa humilde biblioteca, Esperamos que se digne aceitar o nosso convite e honrarnos com sua presença. Queria boa Dona Maria presentear-nos com um pequeno livro ficaríamos sumamente gratos. Esperamos que satisfaça nosso pedido. Abraços dos alunos do $4^{\circ}$ e $5^{\circ}$ ano.

Já no ano de 1942, o Livro de Atas de Comemorações Cívicas, registra suas participação em dois momentos. Nos festejos da Semana da Pátria. No dia 2 de setembro, às 10 horas da manhã, foi realizada a benção da Bandeira confeccionada pelos alunos, tendo como madrinha a professora Maria Mocelini com a assistência de todo colégio e no Dia da Árvore, ao registrar a presenças citam-se os nomes do fiscal de ensino particular, da diretora do Grupo Escolar professora Maria Mocelini, o corpo docente e alunos. O que evidencia sua participação no cotidiano escolar de outras formas que não através da docência.

Em suas escritas, Maria Mocelini não cita suas participações nas celebrações do cotidiano escolar da instituição, mas se refere a outras atividades cotidianas que ocupavam seus dias após a aposentadoria:

Graças a Deus, posso rezar quanto eu quero, o resto do dia remendo a minha roupa, cozo, bordo e faço tricô ou flores. Ao som da campanhia se vai comer. 
Tudo em ordem. Quando posso ir a missa vou, duas meninas que me acompanha. Assim é tudo. Graças a Deus! ( MOCELINI, [1939-1961], p. 17).

Podemos perceber que "meninas" acompanhavam ela à missa. O Colégio Nossa Senhora de Lourdes atendia as meninas do curso ginasial em regime de internato a partir de 1954 (BELUSSO, 2016), e acolhia aspirantes - candidatas a vida religiosa - portanto, interpretamos que as meninas a que ela cita sejam as internas - alunas e/ou aspirantes.

Além disso, foi possível constatar a sua participação em momentos de sociabilidade, tais como: a despedida do Diretor do Grupo Escolar Farroupilha, senhor Júlio Feijó, em 1948. Na ocasião, foi promovido um jantar de confraternização, em que o mesmo, foi homenageado e Maria Mocelini esteve presente (FERNANDES, 2015).

As celebrações destacadas pela professora, junto as irmãs, são duas: a) a comemoração de seus 80 anos de vida; e b) a comemoração de seus cinquenta anos de professora (1907-1957), representado por ela como momentos carinhosamente celebrados. A título de exemplo, apresentamos a escrita da comemoração do aniversário dos cinquenta anos da professora:

Figura 4: Manuscritos Maria Mocelini [1939-1961]

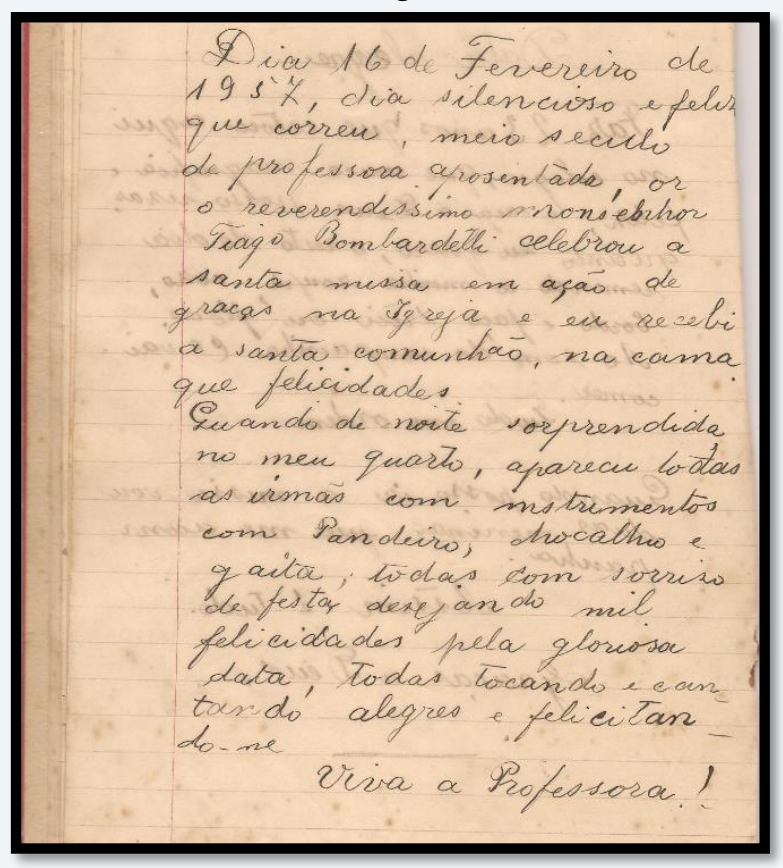

Dia 16 de fevereiro de 1957, dia silencioso e feliz que correu, meio século de professora aposentada, o reverendíssimo Monsenhor Tiago Bombardelli celebrou a santa missa em ação de graças na Igreja e eu recebi a santa comunhão na cama, que felicidades.

Quando de noite, surpreendida no meu quarto apareceu todas as irmãs com instrumentos, com pandeiro, chocalho e gaita, todas com sorriso de festa, desejando mil felicidades pela gloriosa data, todas tocando e cantando alegre e felicitando-me.

Viva a Professora!

Fonte: MOCELINI, [1939-1961], p.18.

Ao comemorar os seus "cinquenta anos de professora aposentada" que, na verdade, constituiam os cinquenta anos a partir de sua nomeação como professora estadual. Percebemos que Maria Mocelini valoriza esse e muitos outros fatos atrelados à profissão docente, em busca 
de uma identidade própria e de uma percepção de si mesma (MIGNOT; BASTOS; CUNHA, 2000) vinculada à sua atuação profissional; e a docência como doação ao saber de uma vida.

Ao narrar a participação das irmãs nessa comemoração, ela as representa de maneira afetuosa em um momento alegre, o que nos faz pensar sobre como e por que essa mulher leiga foi aceita na comunidade religiosa. Dessa maneira, pensamos que por ser uma congregação de origem italiana que tem por carisma o trabalho com o migrante; por Maria Mocelini ter dedicado sua vida exclusivamente à docência; por não ter casado ou formado uma família no município de Farrroupilha; e, por fim, pela sua vinculação com a religião católica, se constituiriam como fatores que contribuíram para esse aceite e cuidado.

No tocante à sua dedicação, à profissão e à vinculação com a religião católica, a professora tem um perfil que se aproxima do professor paroquial. Segundo Kreutz (2004, p. 160) o professor paroquial é o vocacionado e está sob a ótica do sacerdócio, "de um mediador com missão sagrada recebida de Deus e que deveria ser posta a serviço da comunidade”. Tais aproximações justificam, provavelmente, a acolhida da professora, que parece não ter sido apenas formal, como se pode observar na figura 4. A fotografia intitulada "Irmãs da comunidade de Farroupilha", em que posam para o registro as irmãs e a professora Maria Mocelini.

Figura 5: Irmãs da comunidade de Farroupilha [1939-1961]

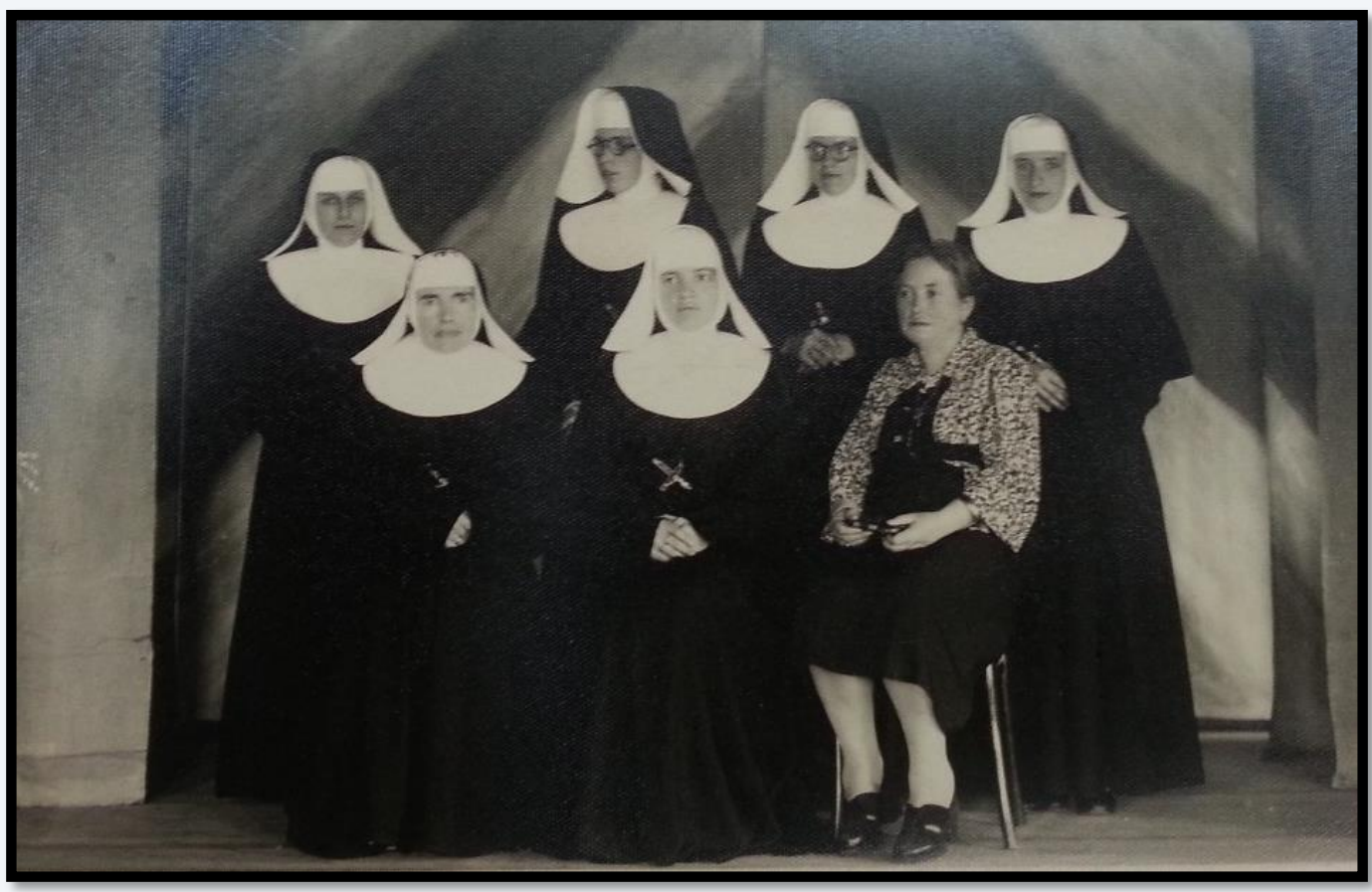

Fonte: Arquivo da Província Imaculada Conceição - Irmãs de São Carlos Borromeo Scalabrinianas.

Esta fotografia foi conservada no arquivo da Secretaria da Província Imaculada Conceição, o qual faz parte do acervo da Congregação das Irmãs de São Carlos Borromeo 
Scalabrinianas. Consideramos que as imagens não são produzidas ao acaso, mas sim, com uma intecionalidade, desta forma, compreendemos que ela foi acolhida pelas irmãs no sentido mais amplo do termo. Pode-se dizer ainda que o processo identitário de Maria Mocelini foi se constituindo em um movimento híbrido entre suas vivências familiares, docentes e na convivência com a comunidade das Irmãs Scalabrinianas.

A docente permaneceu residindo junto à comunidade das Irmãs Scalabrinianas até seu falecimento "aos vinte e quatro dias do mez(sic) de julho de mil novecentos e sessenta e um [...] com oitenta e três anos de idade" conforme o registro no Livro Tombo $\mathrm{n}^{\mathrm{o}} 1$, da Paróquia Sagrado Coração de Jesus, assinado pelo Monselhor Tiago Bombardelli ( LIVRO TOMBO n.1, P.S.C., p. 17). Em homenagem, ainda em vida, o nome da professora Maria Mocelini tornouse o nome de uma escola estadual reunida na localidade de Rio Burati (1958) ${ }^{12}$ e também uma das ruas ${ }^{13}$ centrais do município de Farroupilha (1959).

\section{O refúgio de todos...}

"O Colégio em pé, recebi muitos parabéns, orações." (MOCELINI, [1939-1961],p.1)

Ao tornar as escritas de si de Maria Mocelini como um campo de análise e um refúgio de todos, alguns aspectos tornam-se marcantes no itinerário da professora, dentre eles, dois citados na epígrafe e representados por nós nas palavras Colégio e orações. Destacamos essas palavras, pois após situar sobre a família, a vinda para o Brasil e o tornar-se professora estadual, faz uma imersão em aspectos da vida profissional - Colégio - atrelada à condição religiosa orações. É certo que ao percorrer as memórias autorreferenciais "fica um desejo muito humano de compreender estes outros no tempo, ultrapassando as barreiras da distância temporal e cultural” (CUNHA, 2019, p. 142). Mas apenas fragmentos nos chegam.

Com relação à vida profissional da professora Maria Mocelini, foi possível compreender que ela não exerceu docência no Colégio Nossa Senhora de Lourdes, no entanto, participou do cotidiano escolar em momentos de celebração. Foi servidora pública estadual por 32 anos, sendo 23 anos dedicados nas escolas públicas de Farroupilha. Suas memórias autorreferenciais outorgam-lhe a representação de uma professora comprometida, responsável e de uma pessoa querida pela comunidade. Pelos documentos mobilizados é possível pensar que a professora

12 O Decreto 9823 de 12 de dezembro de 1958 alterou o nome da Escola Reunida do Rio Burati para Escola Reunida Maria Mocelini (CRIVELATTI et. al., 1984).

${ }^{13}$ Lei municipal 403 de 10 de abril de 1959 (GOMES, 2018). 
cumpriu, como muitas, a atividade docente representada como missão, como vocação. Já a vinculação religiosa transcende o tempo de docência, é citada desde a vinda para o Brasil e até os últimos anos de sua vida, quando faz referências à Deus, às orações e ao comparecimento, quando possível, nas missas. Tal vinculação, agregada ao fato da nacionalidade italiana e da aproximação com o perfil do professor paroquial podem justificar a acolhida da professora junto ao Colégio Nossa Senhora de Lourdes após a aposentadoria.

Ao percorrer as páginas das memórias autorreferenciais da professora Maria Mocelini "trilha-se uma leitura em meio a fraturas e dispersão, forjam-se perguntas a partir de silêncios e de balbucios" (FARGE, 2009, p. 91) e a complexidade da vida e da experiência vivida se reduz a páginas breves, a uma escrita circunstanciada por algumas evidências e a muitos esquecimentos. A imigrante italiana que se fez professora pública estadual no Rio Grande do Sul, que permaneceu solteira e que dedicou sua vida para ensinar nos faz pensar sobre muitas representações possíveis a partir dos achados de sua vida, que nos apresentam alguns flashes de seu cotidiano.

Ao arquivar a sua vida, Maria Mocelini dedicou diversas páginas para momentos vivenciados junto às irmãs, por ali inventou um cotidiano em que registra dias felizes em que teve o cuidado e o bem-estar de corpo e alma. Ao que se pôde auferir, ela foi praticamente integrada à comunidade das irmãs, local em que, provavelmente, produziu essas escritas e nos legou o potencial para pensarmos sua vida e sua existência: mulher, migrante, católica e professora. Identidades que puderam ser pensadas, pois "escrever implica colocar-se na posição do sujeito que se encarrega de sua própria palavra, que reconhece sua existência ou pelo menos facilita o caminho para ela" ${ }^{\prime 14}$ (CID, 2001, p. 421). A escrita nos permitiu preservar e entrever representações da vida e do cotidiano da professora Maria Mocelini.

\section{REFERÊNCIAS}

AMELANG, James S. Presentación dossier De la autobiografia a los ego-documentos: un fórum abierto. In: Cultura Escrita \& Sociedad, Universidad del Alcalá, n. 1, p.17-18, sep./2005.

ARTIÈRES, Philippe. Arquivar a própria vida. Revista Estudos Históricos. Rio de Janeiro, CPDOC/FGV, v.11, n.21., p.9-34. Rio de Janeiro, 1998 Disponível em: http://bibliotecadigital.fgv.br/ojs/index.php/reh/article/view/2061/1200. Acesso em: 30 jun. 2017.

\footnotetext{
${ }^{14}$ No original: "escribir implica situarse em posición de sujeto que hace cargo se su propria palavra, que reconoce su existir o al menos facilita el camino para ello" (CID, 2001, p. 421).
} 
BELUSSO, Gisele. Colégio Nossa Senhora de Lourdes, Farroupilha/RS: Histórias de sujeitos e práticas (1922-1954). 2016. 233 f. Dissertação (Mestrado em Educação) Universidade de Caxias do Sul, Caxias do Sul, 2016.

CERTEAU, Michel de. A invenção do cotidiano: artes de fazer. Tradução de Ephraim Ferreira Alves. 2.ed. Rio de Janeiro: Vozes, 1994.

CHARTIER, Roger. A história cultural: entre práticas e representações. Tradução de Marcia Manuela Galhardo. 2. ed. Lisboa: Difusão Editorial, 2002.

CHARTIER, Roger. Os desafios da escrita. São Paulo: Unesp, 2002a.

CID, María de Mar Graña. Leer com el alma y escribir com el cuerpo? Reflexiones sobre mujeres y cultura escrita. In: GÓMEZ. Antonio Castillo (Coord.). Historia de la cultura escrita. Del Próximo Oriente Antiguo a la sociedade informatizada. España: Ediciones Trea, 2001, p. $383-452$.

CUNHA, Maria Teresa Santos. (Des)Arquivar: arquivos pessoais e ego-documentos no tempo presente. São Paulo: Rafael Copetti Editor, 2019.

CRIVELATTI, et. al, A História da Educação no município de Farroupilha. 1984. Trabalho desenvolvido na disciplina de História da Educação II, professor Ivo Adamatti. Caxias do Sul: novembro de 1984.

FARGE, Arlette. O sabor do arquivo. São Paulo: EDUSP, 2009.

FERNANDES, Cassiane Curtarelli. Uma história do Grupo Escolar Farroupilha: sujeitos e práticas escolares (Farroupilha/RS, 1927 - 1949). 2015. 218p. Dissertação (Mestrado em Educação) - Universidade de Caxias do Sul, Programa de Pós-Graduação em Educação, Caxias do Sul, 2015.

FRANZINA, Emílio. A grande emigração. O êxodo dos italianos do Vêneto para o Brasil. Campinas, SP: ed. da UNICAMP, 2006.

GOMES, Antonio Carlos Ruschel. Ruas de Farroupilha: suas vidas e história?

Farroupilha/RS: Ed. do autor, 2018.

HALBWACHS, Maurice. A memória coletiva.Tradução de Beatriz Sidou. 2 ed. São Paulo Centauro, 2006.

KREUTZ, Lúcio. Professor Paroquial: Magistério e Imigração Alemã. Pelotas: Seiva, 2004.

LUCHESE, Terciane Ângela. O processo escolar entre imigrantes no Rio Grande do Sul. Caxias do Sul: Educs, 2015.

MIGNOT, Ana Chrystina Venancio; BASTOS, Maria Helena Camara Bastos; CUNHA, Maria Teresa Santos. Tecendo educação, história, escrita autobiográfica. In: MIGNOT, Ana Chrystina Venancio.; BASTOS, Maria Helena Camara Bastos; CUNHA, Maria Teresa Santos Cunha.(Org.). 2000. Refúgios do eu: educação, história e escrita autobiográfica. Florianópolis: Mulheres, 2000. p.17-28. 
MIGNOT, Ana Chrystina Venancio; BASTOS, Maria Helena Camara Bastos; CUNHA, Maria Teresa Santos.(Org.). Refúgios da educação, história e escrita autobiográfica. Florianópolis: Mulheres, 2000. p. 9-16.

NORA, Pierre. Entre memória e história: a problemática dos Lugares. Projeto História. São Paulo, n. 10, p. 7-28, 1993. Disponível em http://revistas.pucsp.br/index.php/revph/article/viewFile/12101/8763. Acesso em: 12 abr. 2015.

PESAVENTO, Sandra Jatahy. História e história cultural. 2. ed. Belo Horizonte: Autêntica, 2008.

POLLAK, Michael. Memória, esquecimento, silêncio. Estudos Históricos, Rio de Janeiro, v. 2, n.3, p.3-15, 1998.

RECKZIEGEL, Ana Luiza Setti e AXT, Gunter (Dir.). República. República Velha (1889 1930). Passo Fundo: Méritos, 2007, v. 3, t. 1, 2007.

SARLO, Beatriz. Tempo passado. Cultura da memória e guinada subjetiva. São Paulo: Companhia das Letras; Belo Horizonte: UFMG, 2007.

TRENTO, Angelo. Do outro lado do Atlântico. Um século de imigração italiana no Brasil. São Paulo: Nobel, Instituto Italiano di Cultura di San Paolo, Instituto Cultural Ítalo-Brasileiro, 1989.

VIÑAO FRAGO, Antonio. A modo de prologo, refugios del yo, refugios de otros. In: MIGNOT, Ana Chrystina Venancio; BASTOS, Maria Helena Camara Bastos; CUNHA, Maria Teresa Santos. Tecendo educação, história, escrita autobiográfica. In: MIGNOT, Ana Chrystina Venancio.; BASTOS, Maria Helena Camara Bastos; CUNHA, Maria Teresa Santos Cunha.(Org.). 2000. Refúgios do eu: educação, história e escrita autobiográfica. Florianópolis: Mulheres, 2000. p. 9-15.

Las autobiografías, memorias y diarios como fuente histórico-educativa: tipología y usos. Teias. Rio de Janeiro: UERJ, v.1,n. 1. p.1-26. 2000a. Disponível em: file://C:/Users/Gisele/Downloads/23827-76663-1-PB.pdf. Acesso em 30 de jun. de 2017.

Historia de la educación y historia cultural: posibilidades, problemas, cuestiones.

Revista Brasileira de Educação, Campinas, SP, n. 0, p. 63-82, set./out./nov./dez. 1995. Disponível em: http://anped.tempsite.ws/novo_portal/rbe/rbedigital/RBDE0/RBDE0_06_ANTONIO\%20VIN AO_FRAGO.pdf. Acesso em: 9 jun. 2019.

\section{ENTREVISTAS}

SEGANFREDO, Mafalda. Entrevista concedida a Gisele Belusso. Farroupilha, 04 de agosto de 2015. Entrevista. 


\section{DOCUMENTOS ACESSADOS}

Caderno manuscrito de memórias de Maria Mocelini [1939 - 1961].

Caderno escolar do ensino primário de Dulce Tartarotti, 1940.

Fotografia do acervo da Secretaria da da Província Imaculada Conceição - Congregação das Irmãs de São Carlos Borromeo Scalabrinianas.

Jornal ‘A Federação’. Órgão do Partido Republicano. Porto Alegre, RS.

Jornal 'A Cittá di Caxias'. Periódico semanal de interesse colonial. Diretor E. Scorza. Editor gerente e proprietário Emílio Fonini. Caxias, RS.

Jornal O Regional. Órgão dos interesses da região colonial italiana do Estado. Diretor e gerente Luiz Miranda. Caxias, RS.

Livro Tombo número 1, Paróquia Sagrado Coração de Jesus, Farroupilha, RS.

Relatório dos Intendentes de Caxias do Sul. Arquivo Histórico de Caxias do Sul, RS.

Livro de atas de comemorações cívicas do Colégio Nossa Senhora de Lourdes, 1942.

\section{SOBRE AS AUTORAS:}

\section{Gisele Belusso}

Doutoranda em Educação no Programa de Pós-Graduação em Educação da Universidade de Caxias do Sul (UCS); Membro do Grupo de Pesquisa História da Educação, Imigração e Memória (GRUPHEIM); Bolsista Capes. E-mail: giselebelusso@ hotmail.com

iD http://orcid.org/0000-0003-1721-477X

\section{Terciane Ângela Luchese}

Doutora em Educação, Pós-Doutora em História da Educação pela Università Degli Studi del Molise e Università di Macerata. Professora do Programa de Pós-Graduação em Educação e Programa de Pós-Graduação em História da Universidade de Caxias do Sul (UCS). Líder do Grupo de Pesquisa História da Educação, Imigração e Memória (GRUPHEIM). Bolsista em Produtividade em Pesquisa CNPq, Pesquisador Gaúcho FAPERGS.E-mail: taluches@ucs.br (iD http://orcid.org/0000-0002-6608-9728 